\title{
Archaeological Exploration of Defence Structures \& Fortress City Based on Ancient Folklore of Mount Abu, Rajasthan, India
}

\author{
Priyank Talesara, Aniruddh Bahuguna, Chintan Thakar
}

\begin{abstract}
In terms of archaeology the defence structure defined as protective or fortification construction or enclosure around any settlement on the area with or without a moat. In an archaeological context, defence structures are mainly constructed on a formal or informal plan and consist of walls and fortification built in massive size. In our winter exploration, we tried to investigate the discovery of the ruins of defence structure found near sacred place/pilgrimage site in Sirohi District. Methodology: Our field survey in Sirohi district based on ancient folklore of Mount Abu to relate its multidisciplinary archaeological science related to the field of geography about the number of defence structures \& fortress city. Remote sensing and GIS applications use to tracing the geo-coordinate location of structures and ruins. Also tries to focus on the contour of the area to know its higher-point, elevation and even measured MSL. Aim \& Objective: In the history of Sirohi, only a few forts have been reported for example Basantgarh/Vasantagar, Chandrawati, Achalgarh, Sirohi city fort. First, three cities established in ancient time especially Vasantgarh is the oldest fortress city in the district. but What was purpose behind building these forts? What was the role of fortified temple in the kingdom? What trade links it have through trade routes and links with other kingdom? Why these cities got destroyed? We found ruins of defence structure near Vastanji, Gharkav Mata Ji, Shergaon, Utraj and Oriya. These sites are explored near Mount Abu. Conclusion: Most of the sites in above finding seem to possibly destroy in the earthquakes as these sites located near Seismic fault zone and here we found fallen ruins, large scattered rocks and buried cities mound. Most of the Modern settlement of Sirohi district built their houses on the buried mound. Still, sometimes villagers finding here artefacts related to historical settlement of ancient cities. In the end, we like to conclude that the geography of the area is very difficult to explore in a short period, our exploration continues. Abu.

Keywords: Defence Structure, Earthquakes, Folklore, Mount
\end{abstract}

\section{INTRODUCTION}

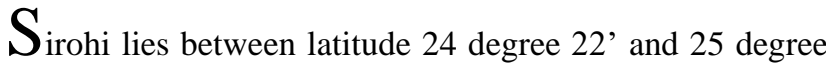
$16^{\prime}$ 'N., and between longitude 72 degree $22^{\prime}$ and 78 degree $18^{\prime}$ E. Its area is 1964 square miles [1, p. 280]. It is bounded on the north by Marwar; on the east by Meywar; on the south by Palanpur, Edar, and Danta; and on the west by Marwar $[1$, p. 280]. This area is not easy to explore without taking any

Revised Manuscript Received on April 30, 2020.

* Correspondence Author

Priyank Talesara* Ancient Indian History, Culture \& Archaeology, Madhav University, Abu Road, India. Email: thelostworld.in@gmail.com

Aniruddh Bahuguna, Ancient Indian History, Culture \& Archaeology, APS University, Rewa, India. Email: aniruddhbahuguna91@gmail.com

Chintan Thakar, Ancient Indian History, Culture \& Archaeology, Madhav University, Abu Road, India. Email: dave.melodious@gmail.com

(C) The Authors. Published by Blue Eyes Intelligence Engineering and Sciences Publication (BEIESP). This is an open access article under the CC BY-NC-ND license (http://creativecommons.org/licenses/by-nc-nd/4.0/) risk because ethnic class Grasia and Bhil are so violent towards modern society.

\section{BACKGROUND}

\section{A. Folklore of Mount Abu}

According to ancient legend, Rishi-Vashistha's (Sage) cow falls in Brahmakhai (great deep gorge). While Mediation Vashistha got the vision that, his cow Nandini falls in Brahmakhai. Vashistha asked his cow to come out from gorge. Unexpectedly miraculous Nandini itself released too much milk like a river, by using buoyancy force Nandini came out from gorge. In rumination, Vashistha decided to praise Lord Shiva to fill-out the gorge, to curb the accidents in future. Vashistha impetus grand Yajna, he solicits thirty-three Koti gods i.e. twelve Aditya, eleven Rudra, eight Vasus, Indra and Prajapati. Apart from thirty-three Koti gods, Vashitha also invited Himalaya to solve the problem, but Himalaya sends his elder son Aravalli to escalate the problem. On the arrival, Aravalli was terrified after seeing the depth of the Brahmakhai. He gave up and returned to his father, and then Himalaya sends his younger lame son Nandivardhan. Nandivardhan seated on the back of Arbud Nag (serpent) and visited Vashistha. But even Nandivardhan shocked after seeing the depth of the gorge and started thinking that how he can solve this problem of this gorge as he is physically disabled. Finally, he acquires some courage and decides to solve the problem, he asked Vashistha to grant him two blessings i.e. First, that his body remains guarded by thick green vegetation. And second, for his protection 'he should get the blessing of all thirty-three Koti gods'. Now for the fulfilment of the second wish Lord Shiva (the main god of Yajna) appears and said Tathashtu (wish granted), then suddenly Arbud Nag asked that how he will remain safe? Because as a carrier, he is going to be part of the task. Then Nandivardhan grants immunity to Arbud Nag and also assure that, this effected region will be known by his name 'Arbud' in future. Nandivardhan with Arbud Nag then jump through the escarpment into the gorge and memorise Lord Shiva to grant immunity. In the meantime Lord Shiva was in Kashi (Varanasi City), so he moved his one foot stretched towards Achaleshwar (sacred area in Mount Abu) through his toe, due to this action a strong temblor occurred that knocked down rocks and help filled the Bhramakhai. Lord Shiva lifted Nandivardhan with his toe to save them and helps complete the task. The toe impression of Shiva still could see in Achaleshwar temple inside the Natural pit formed as Shivlinga, the pit is filled with a natural water source. This Natural pit still called Brahmakhai.

\section{Published By:}

Blue Eyes Intelligence Engineering 10 \& Sciences Publication (C) Copyright: All rights reserved. 


\section{Archaeological Exploration of Defence Structures \& Fortress City Based on Ancient Folklore of Mount Abu, Rajasthan, India}

According to this legendary story, after Yajna completed Lord Shiva and Vishnu and all remaining thirty-three Koti gods reside in Vastanji area, sages also reside here in Vastanji or Vastaneshwar. The temple was named after sage Vashistha because the Yajna was organised by him. Temple area is called Vastanji or Vastaneshwar (eshwar means Shiva). The whole mountain plateau was named as Mount Arbud or Mount Abu in the regard of Arbud Nag.

\section{ARCHAEOLOGICAL FINDINGS}

\section{A. Exploration track of Vastanji}

Vastantji or Vasthaneshwar temple (24.706853, 72.811634) located in village Isra foothills of Mount Abu in Sirohi district, in ancient time this district was referred as Aburaj or Abumandal/Arbud were too many sacred temples built which were fortified and protected by defence structures. Vastanji temple is also known as Aburaj. Temple is located 35 kilometres (walk path) from Mount Abu hill station. It is believed here Arbud serpent use to live here. This important sacred site of the natural cave here ancient time installed with the sacred images of the deities representing adore of Vaishnavism and Shivanism.

\section{B. Documentation of Vastanji}

Vastanji temple is a cave temple, Garbhagriha (sanctum sanctorum) was developed inside the cave, outside of cave observed two Nandi (hump bull a sacred carrier of Lord Shiva) one with inscription in Devanagri script (figure no. 1),

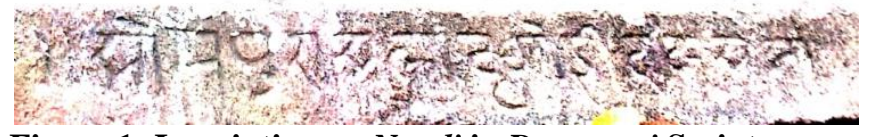

Figure 1: Inscription on Nandi in Devanagri Script.

with two Shivlinga (non adored), another three Nandis with tortoise facing towards Shivlinga and fourteen idols of other deities covered with ritualistic cosmetics like Rangbhog and coloured metal foil caused difficult to identify, and last one beautiful Vishnu idol (figure no. 2) which shows wonderful features of iconography manifestation.

Inside the cave, we notice black stone anthropomorphic Garuda (combination of eagle and human) idol, which seems to be Garuda-Dhawaj (sacred symbol and vehicle mount of Vishnu). Its hands is in Anjali-Mudra (welcome posture) seems to hold Gada (mace), one foot is folded \& another one pressing serpent. Garuda idol is facing towards the beautiful huge black stone idol of Dashavatar Vishnu. Other than Dashavatar Vishnu there is also one Shivalinga, one Parvati goddess, one Ganesh idol and one beautiful colourful idol of the unidentified deity.

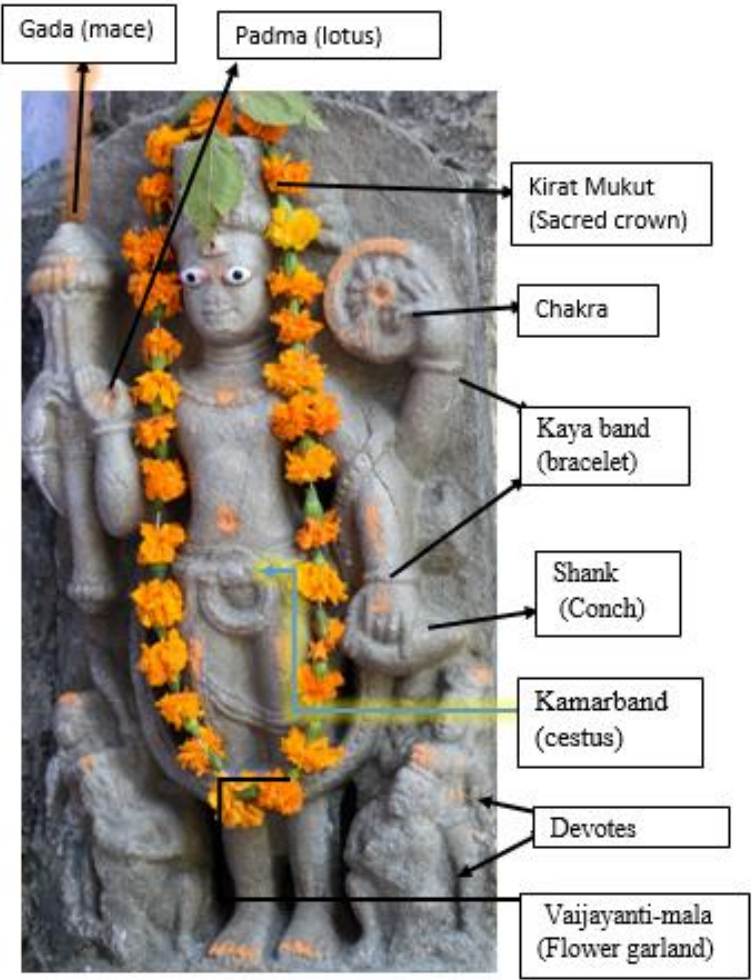

Figure 2: Iconography of Vishnu

Few meters towards upside on the hill from cave temple Vastanji, another cave no. 2 located which have sacred fire altar (Agnikund) inside it. Outside of the cave, the sacred $O M$ symbol was drawn in ochre colour which means still worship by local people. Here found buried broken pieces of the terracotta jar it was round in shape and all two-part of ancient grinder easily could be noticed outside cave no. 2. While continuing the exploration towards the lofty hill, after approx 200 meters found cave no. 3, it has a beautiful partially survived rock art (figure no.3) of a war scene, the mural shows one camel rider and one horse rider and three infantry worriers, all wearing armour with weapons like swords in hand. This medieval period rock art crafted with white lime powder and highlighted by black charcoal powder. The subject is very prominent looks like drawn by some professional.

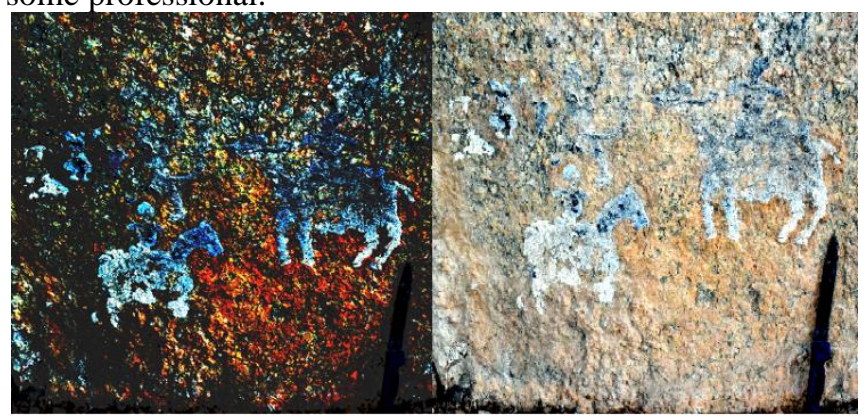

Figure 3: (a) and

(b)

(a) Processed by low frequencies in seven channels RGB graph.

(b) Enhanced by Auto tone Max 6\% high.

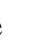


Continuing the exploration, towards forest pathway from cave no. 3 (24.705852, 72.809874), approx after 350 meters in right direction found the unique defence structure, a large manmade fortified cum natural cave no. 4 (figure no. 4). The open side of the cave no. 4 is fortified by the wall of $6 \mathrm{ft}$ in height made up of large stones slabs with mortar. Near the cave no. 4 found lots of shreds of pottery and bricks, bricks size are $32 \times 24 \times 5 \mathrm{cms}$ is related to the Parmar phase of Chandrawati. [1, p. 282] Possibly this type of defence structure is used for hideout purpose because, in the period of warfare, Parmars were constructing places for the hideout. [2, p. 15]

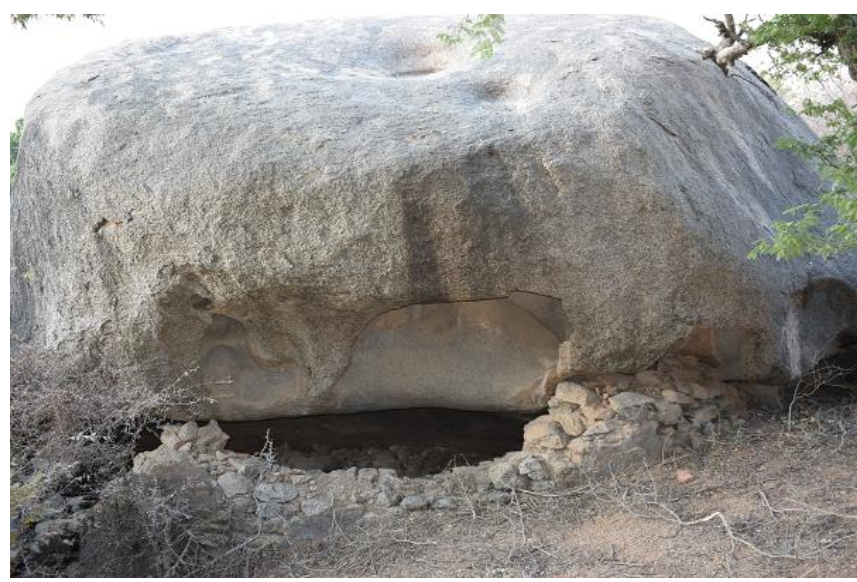

Figure 4: Cave no. 4, seen small portion of wall from outside.

\section{C.Exploration track near Gharkav Mataji}

Gharkav Mataji (24.654301, 72.859858) located in village Kachholi (Pindwara Tehsil in Sirohi district), which is located 25 kilometres from Sirohi. Few meters from the temple, towards upside the foothills, found broken part of Jain sculpture (24.655001, 72.858330), looks like a part of the column of the temple. After continuing exploration few meters away from one cairn circle burial was identified, burial has large stones in circular positions and contains one hero stone (figure no.5) shows an impression of a archer warrior in traditional costume with bow and arrow in hand, sun and moon on top, which is adored by local tribes here.

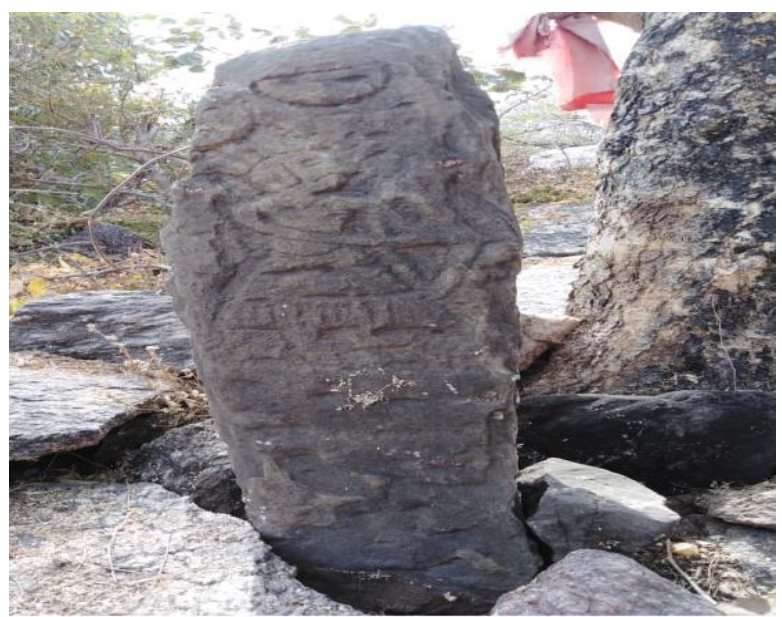

Figure 5: Hero Stone

To discover more finding we began to track and after approx 250 meters found Ruins of fortress or citadel (24.656227, 72.856123), the roof is fallen on the structural complex -1 (figure no.6), the roof is made up of strong mortar (Khodd) material, identified two equal partition shows in middle explains three chambers for the structural complex -1. Approximate area of the complex is $302 \mathrm{M}^{2}$, the length of all four walls are $20.59 \times 19.34$ x $16.02 \times 14.73$ Meters. Just above this complex on the steep ascent of the foothills identified a large watch-tower build by huge stone slabs, the speciality of the watch-tower is its height and visibility facing rift valley having the view of river West-Banas and mount valley plans. Residential evidence like potteries, potsherds and one hopscotch stone is found near the watch-tower.

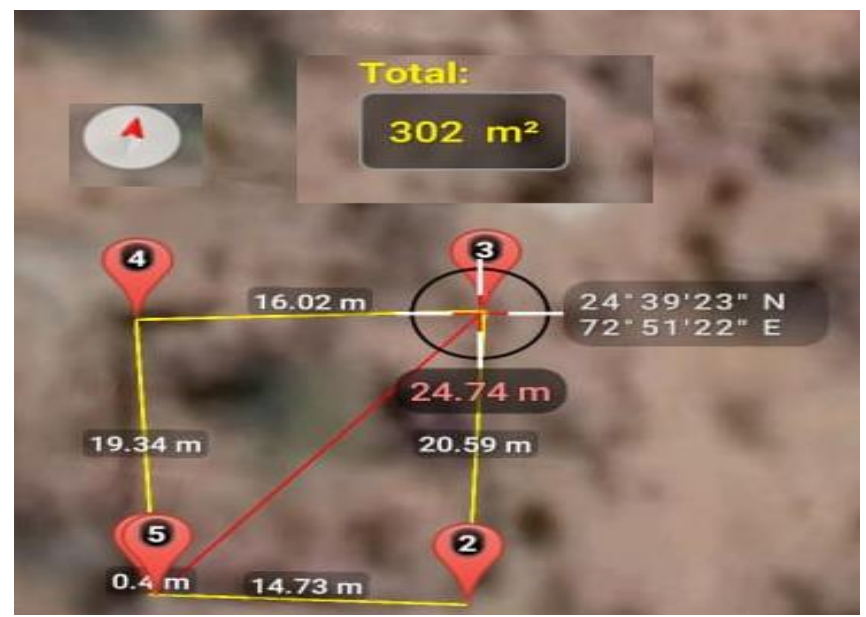

Figure 6: GIS map of Structural Complex -1

Approx 50 meters in south of watch-tower, we found ample ruins of defence structures, pillars (figure no.7) and other parts like Lotus structure (figure no. 8) meant for holding the weight of buildings of the temple. Some buried walls in a circular shape and straight alignment line are identified; large mound was seen with a thick white locus of soil evidence human activity. Most of the unidentified structural complexes are buried in the mound.

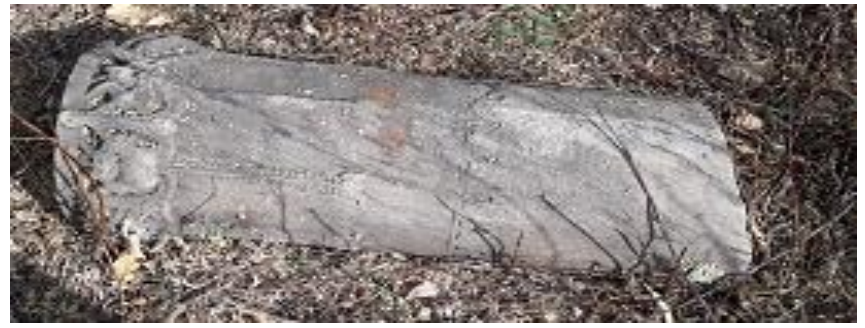

Figure 7: Part of the temple, Pillar

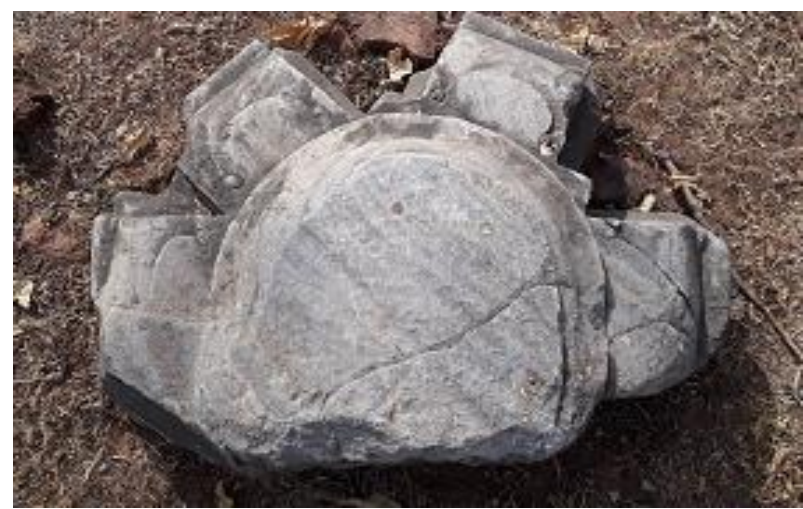

Figure 8: Part of a temple, Lotus Structure.

Published

Blue Eyes Intelligence Engineerin \& Sciences Publication

(C) Copyright: All rights reserved.

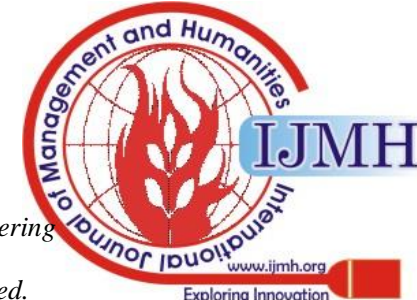




\section{Archaeological Exploration of Defence Structures \& Fortress City Based on Ancient Folklore of Mount Abu, Rajasthan, India}

With the help of GIS applications two more structural complexes -2 \& 3 (24.663453, 72.847873) found in the closed valley (figure no. 9), approx 1.2 Kilometers north to the watchtower. The approximate area of these structural complexes is $243 \mathrm{M}^{2}$ and $170 \mathrm{M}^{2}$ respectively. The wall of the structural complex -2 is not in a rectangular form but its longest wall-size length is 22.47 Meters. And structural complex -3 is circular.

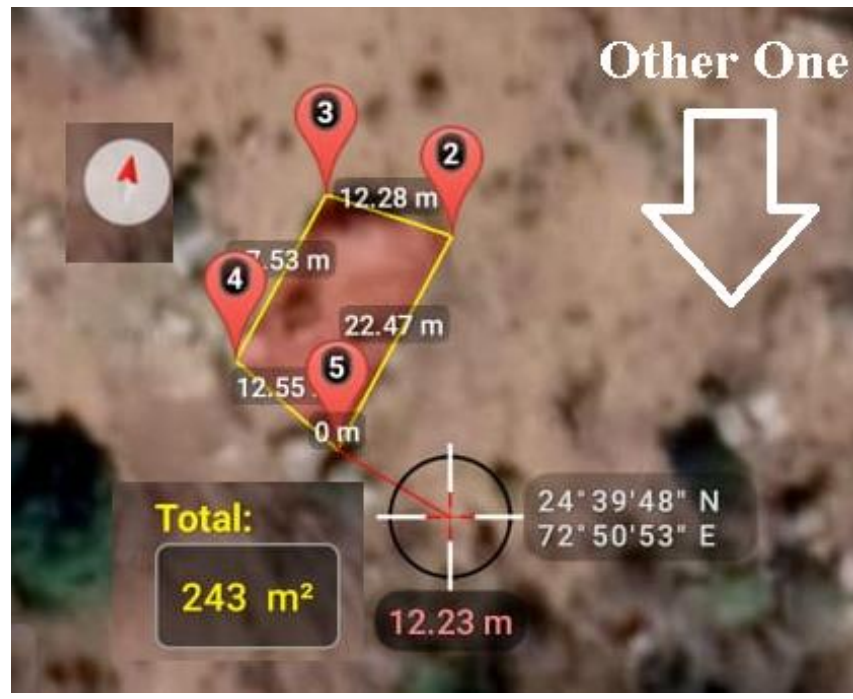

Figure 9: GIS Map of Structural Complex - 2 \& 3

\section{Exploration of Oriya}

The village Oriya is 7.5 kilometres away from Mount Abu. Here found ruins of an ancient temple (24.630320, 72.763373), the temple consists of Vishnu idol and one unique inverse Shivaling. There is an open well attached to the temple. This temple is located on the River terraces. There are ruins of many structural complexes buried in the seasonal stream terraces. Few meters in the west direction there is a cave -5 , the cave is closed by a gate and inside there is an impression of a big hand on the roof side, it's looked like carved but according to tribal folk this impression made by Bhim of Mahabharata. Moreover, in the cave, we also found ancient Shivaling

\section{E. Exploration of Shergaon}

Shergaon is 21 kilometres from Mount Abu. This place is isolated from the modern world. No route for this village, way to reach Shergaon is very difficult, a person needs to cross many steep hills to reach the place, ethnic people are disconnected from the society, they are still following traditional surviving methods, the main meal of people is maze Chapati and curd curry, and they used to drink hot tea made of special wild lemon tree leaves. A strange tradition is observed, all the ethnic people used to live in two different places. All people live in the upper plateau of the village in summer and rainy seasons and lower plateau of the village in the winter season. Maybe there is a strategy behind this system to cope with weather and temperature problems. Found here Cave -6 , this cave is identical to the manmade fortified cum natural cave no. 4 of Vastanji, $50 \%$ part of the cave is fortified with long, thick and strong fortification made of stone and mortar. Other than that three natural ponds are identified with one Ishan Bheru Temple, all of them are used by ethnic people.

\section{F. Exploration of Akhi}

Retrieval Number: H0832044820//2020@BEIESP

DOI: 10.35940/ijmh.H0832.044820

Journal Website: www.ijmh.org
Here trace ruins of ancient fortress (24.658691, 72.813173) area with the help of GIS, located in the steep top of foothills in hinterland area. From the local people, we got the news that ruins of fortified structure in Akhi village. This village is too far and very difficult to reach, located on the top of the lofty mountain. So we planned to trace these structures from remote sensing applications, which show the vision of fortified three structures (figure no.10) which we marked it with points and measured it, approximate two of them are identical with each $21 \mathrm{M}^{2}$, and another large one is $174 \mathrm{M}^{2}$.

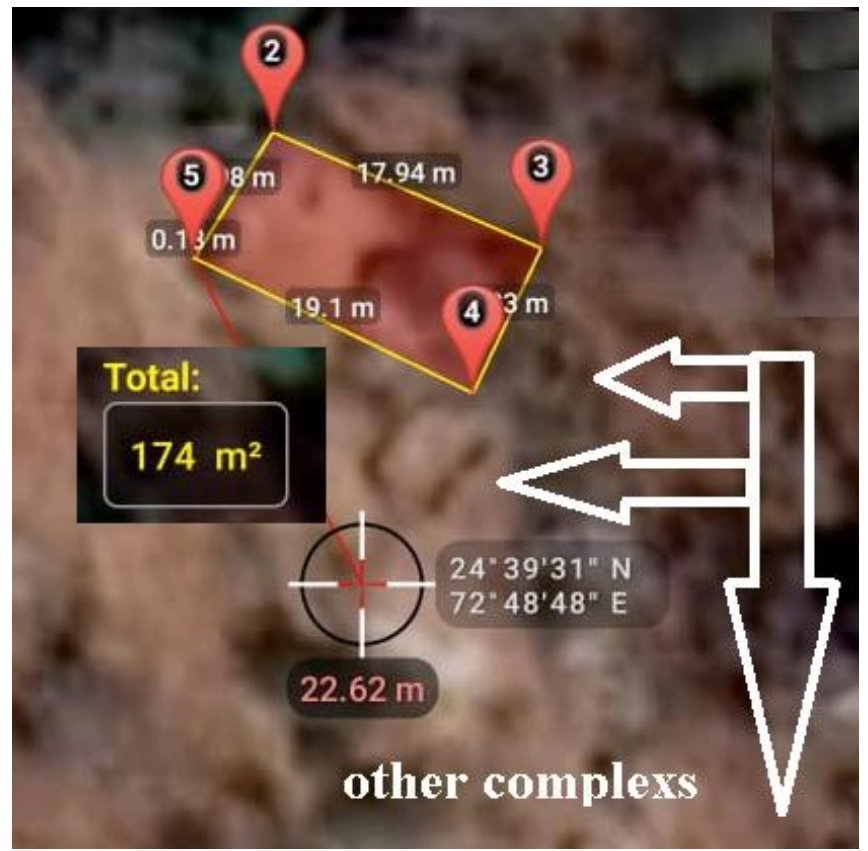

Figure 10; Akhi Village Structural Complexes

\section{G. Lotana Exploration}

Sartaneshwar temple is located in the village Lotana, which is about $59.1 \mathrm{Km}$. from the Mount Abu. It is a Shivanism temple. This area is located in a dense forest; the structure is fortified Shiva temple on the foothills near the seasonal downstream. Here we documented discarded idols; these are kept inside the premises of temple step-well. Most of the ruins of temple scattered in the premises of the stepwell. This premise is prohibited for all other than the main priest of the temple. Here Identified one unique Vishnu idol, which has twenty hands (figure no. 11), one Narshima Avatar shows the scene of crushing the demon Hiranyakashipu. Inside the premise of the room covered Stepwell, observed one large damaged Toran Jamb with Yogeshwar, his mount Nandi and one attendant. Other idols are Gaja-Laxmi, Chaturbhuj Vishnu, Sun Idol, and Shivalinga.

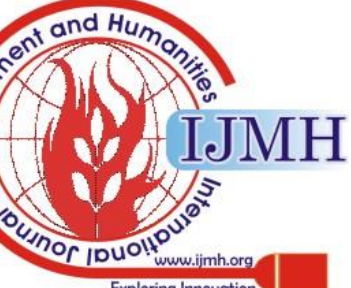




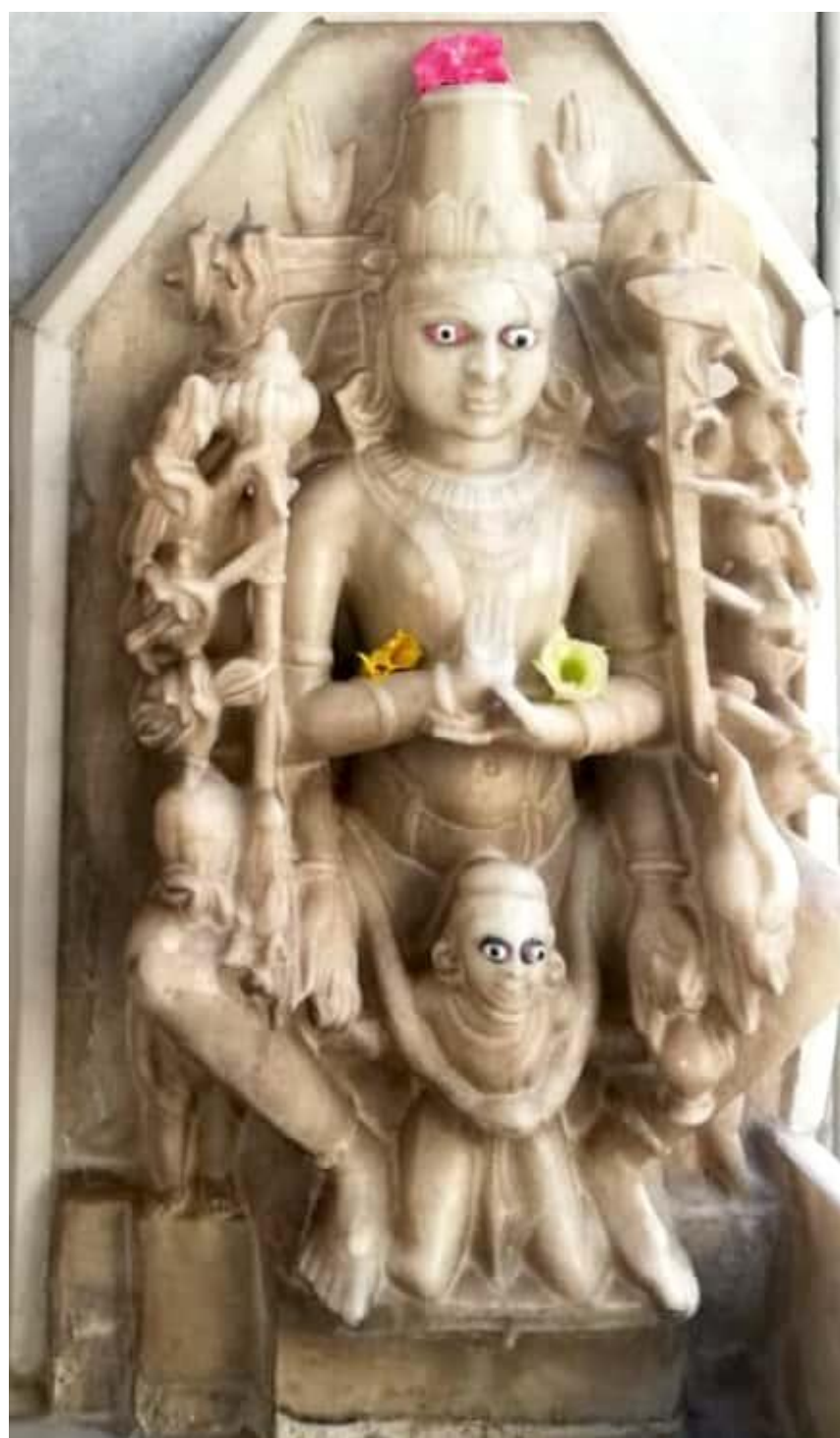

Figure 11: Unique Idol of Vishnu with 20 Hands

\section{FINDING}

These fortified areas seem to have a link with other fortress kingdoms of Sirohi like earlier reported area like Vasantgarh,

Achalgarh, Chandrawati and Bhandhiyagarh. [1, p. 282] As these kingdoms are developed in Parmar phase, even these sacred sites also show ruins and brick size of the same phase. Moreover, in our earlier finding, we explored the fortress area of Bandhiyagarh area near the hills of Soorpagla village. On fortress area of Bandiyagarh, contemporary dates are 1154 A.D. and 1195 A.D. [3]

\section{POSSIBILITY \& CONCLUSION}

We found hero-stone near Gharkhav Mataji which have image of archer who looks identical to the Warrior in Rock art of cave no - 3 of Vastanji. Both warriors are in the traditional Costume which makes possibility that both are contemporary. Building large of numbers of forts, temples and other defence structures in late seventh century to late thirteenth century, this period known as era of Arab invaders and also the part of Silk route, So the ancient temples and forts played an important role in defence. [2, p. 19].We likes to tell that this is an earthquake-prone area. And many sites which have been mentioned in above finding seems to

possibly destroyed in the earthquakes as these sites located near fault zone and here we found fallen ruins, large scattered rocks and buried cities mound. Modern settlement of Sirohi district built their houses on the buried mound. Still, sometimes villager finding here artefacts related to historical settlement of ancient cities. Due to the warfare contemporary thrones tried to build some hideout places in the difficult geography of Mount Abu. In the end, we like to conclude that geography is very difficult that we still finding fortified cities that our exploration continues.

\section{SUGGESTIVE READINGS}

\section{- $\quad$ Rigveda Translation Ralph T.H. Griffith}

\section{WORKS CITED}

1. Priyank Talesara, Aniruddh Bahuguna, "An archaeological documentation and investigation on fortification discovered in the Aravalli range, Rajasthan," Rajasthan Archaeology \& epigraphy congress, vol. 1, no. feb, pp. 280-294, 2020.

2. Priyank Talesara \& Aniruddh Bahuguna, "Archaeological Exploration of Sirohi District, Rajasthan," IOSR Journal of Humanities and Social Science, vol. 25, no. 2, pp. 14-19, 2020.

3. Priyank Talesara \& Aniruddh Bahuguna, "Archaeology of Bandiyagarh, Sirohi district of Rajasthan," Shodh Patrika, p. proceedings, 2020

\section{AUTHORS PROFILE}

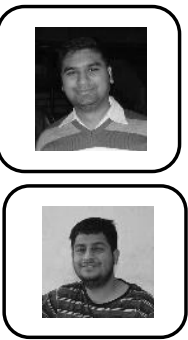

Priyank Talesara, Archaeologist, Assistant Professor, Madhav University Member of Russian Geographical Society, Director of Exploration in Sirohi, ASI \& MU 2018-20

Aniruddh Bahuguna, Ph.D Scholar, APS University

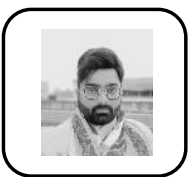

Chintan Thakar, Archaeologist, Assistant Professor, Madhav University

Joint Director of Exploration in Sirohi, ASI \& MU 2019-20

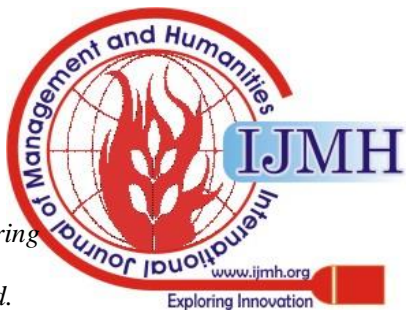

